\title{
Effect of timing of initiation of resynchronization and presynchronization with gonadotropin-releasing hormone on fertility of resynchronized inseminations in lactating dairy cows
}

\author{
G. Lopes Jr., J. O. Giordano, A. Valenza, M. M. Herlihy, J. N. Guenther, M. C. Wiltbank, and P. M. Fricke ${ }^{1}$ \\ Department of Dairy Science, University of Wisconsin, Madison 53706
}

\begin{abstract}
Lactating Holstein cows $(\mathrm{n}=1,456)$ were randomized in a $2 \times 2$ factorial design to compare the main effects of day of initiation of resynchronization after artificial insemination (AI; 32 vs. 39 d) and presynchronization with GnRH 7 d before initiation of resynchronization on fertility to timed AI (TAI). This design resulted in the following 4 resynchronization treatments: (1) resynchronization $\left(\mathrm{GnRH}\right.$ treatment, $\mathrm{PGF}_{2 \alpha}$ treatment $7 \mathrm{~d}$ later, $\mathrm{GnRH}$ treatment $56 \mathrm{~h}$ later, and TAI $16 \mathrm{~h}$ later), initiated $32 \pm 3 \mathrm{~d}$ after $\mathrm{AI}$; (2) presynchronization with $100 \mu \mathrm{g}$ of $\mathrm{GnRH} 25 \pm 3 \mathrm{~d}$ after AI and resynchronization initiated $32 \pm 3 \mathrm{~d}$ after AI at nonpregnancy diagnosis; (3) resynchronization initiated 39 \pm 3 d after AI (GPG39); and (4) presynchronization with $100 \mu \mathrm{g}$ of GnRH $32 \pm 3 \mathrm{~d}$ after AI at nonpregnancy diagnosis and resynchronization initiated $39 \pm 3$ $\mathrm{d}$ after AI. Overall, 344 cows were inseminated at estrus between enrollment ( $25 \pm 3 \mathrm{~d}$ after $\mathrm{AI})$ and TAI of the resynchronization treatments, and 1,112 cows received TAI. Progesterone (P4) was analyzed in blood samples collected from all cows at the first $\mathrm{GnRH}$ injection of the resynchronization protocols (G1), and ovarian structures were evaluated and blood samples were collected at G1, at the $\mathrm{PGF}_{2 \alpha}$ injection, and at the TAI of the resynchronization protocols in a subgroup of cows $(\mathrm{n}=417)$. When analyzed as main effects, cows presynchronized with GnRH had more pregnancies per AI (P/AI) than nonpresynchronized cows (38.9 vs. 33.8\%), whereas timing of initiation of resynchronization did not affect P/AI. Although cows with high P4 at G1 had greater $\mathrm{P} / \mathrm{AI}$ than cows with low $\mathrm{P} 4$ (38.7 vs. $31.8 \%$ ), presynchronization with GnRH did not increase the proportion of cows with high $\mathrm{P} 4(>1.0 \mathrm{ng} / \mathrm{mL})$ at G1 but moved cows from a low-P4 environment to an intermediate-P4 level. Presynchronization with $\mathrm{GnRH}$ also decreased the percentage of cows with low $\mathrm{P} 4$ at the $\mathrm{PGF}_{2 \alpha}$ injection, thereby increasing synchrony to
\end{abstract}

Received November 27, 2012.

Accepted March 5, 2013.

${ }^{1}$ Corresponding author: pmfricke@wisc.edu the protocol. Cows with high P4 at G1 had a decreased ovulatory response to G1 compared with cows with low P4 (40.9 vs. $69.1 \%$ ), and cows that ovulated to G1 had decreased luteal regression after $\mathrm{PGF}_{2 \alpha}$ compared with cows that did not ovulate (78.5 vs. $87.3 \%$ ). We conclude that presynchronization with GnRH 7 d before initiation of resynchronization increased fertility in dairy cows, whereas timing of initiation of resynchronization did not.

Key words: presynchronization, resynchronization, gonadotropin-releasing hormone, dairy cow

\section{INTRODUCTION}

Many confinement-based dairy systems in the United States have adopted systematic synchronization protocols that allow for timed AI (TAI) for first AI service, thereby reducing the impact of poor detection of estrus (Pursley et al., 1997; Caraviello et al., 2006). The strategy for resynchronization of ovulation on most dairy farms often relies on the timing of initiation of the Ovsynch protocol or variations of the Ovsynch protocol after insemination (Fricke et al., 2003; Bartolome et al., 2005; Sterry et al., 2006a). In most experiments, there are usually fewer pregnancies per AI (P/AI) to TAI after resynchronization compared with TAI at first service (Galvão et al., 2007; Silva et al., 2009; Thompson et al., 2010), indicating that fertility to TAI after resynchronization is not optimized.

Poor fertility of resynchronized cows is related to progesterone (P4) concentration at initiation of the resynchronization protocol. Between 15 and $26 \%$ of cows lack a corpus luteum (CL) or have low P4 at initiation of resynchronization (Fricke et al., 2003; Sterry et al., 2006b; Silva et al., 2009), resulting in development of the preovulatory follicular wave in a low-P4 environment. Development of follicles in a low-P4 environment is associated with reduced embryo quality (Rivera et al., 2011) and fertility (Folman et al., 1990; Wiltbank et al., 2012) in lactating dairy cows. Therefore, we hypothesized that presynchronization with $\mathrm{GnRH} 7$ $\mathrm{d}$ before initiation of the resynchronization protocol would increase fertility by inducing ovulation in some 
cows, thereby increasing P4 $7 \mathrm{~d}$ later at the first GnRH injection of the resynchronization protocol.

Many dairies start the resynchronization protocol after a negative pregnancy diagnosis $39 \pm 3 \mathrm{~d}$ after $\mathrm{AI}$ or $32 \pm 3$ d after AI (Pursley et al., 1997; Stevenson et al., 2003); however, no data exist directly comparing fertility of cows that initiate the resynchronization protocol $32 \pm 3$ versus $39 \pm 3 \mathrm{~d}$ after a previous AI. Based on a 23-d interovulatory interval in lactating cows (Sartori et al., 2004) and data supporting that the best time to start the Ovsynch protocol is during the early luteal phase, around 5 to $9 \mathrm{~d}$ after ovulation (Vasconcelos et al., 1999), we hypothesized that the ideal time to initiate resynchronization would occur between 28 to $32 \mathrm{~d}$ after a previous AI.

In the present study, we compared the main effects of (1) presynchronization with GnRH $7 \mathrm{~d}$ before initiating the resynchronization protocol and (2) initiating the protocol either $32 \pm 3$ or $39 \pm 3 \mathrm{~d}$ after a previous insemination. Our hypotheses were (1) that P/AI would be greater for cows presynchronized with GnRH $7 \mathrm{~d}$ before initiation of resynchronization compared with cows not presynchronized and (2) that P/AI would be greater for cows initiating the resynchronization protocol at $32 \pm 3 \mathrm{~d}$ compared with $39 \pm 3 \mathrm{~d}$ after a previous insemination.

\section{MATERIALS AND METHODS}

\section{Cows and Reproductive Management}

This experiment was conducted in collaboration with a dairy farm located near Pickett (Wisconsin) milking approximately 8,000 cows. Cows were housed in cross-ventilated, freestall barns and were fed a TMR once daily to meet or exceed the dietary requirements for lactating Holstein cows weighing $680 \mathrm{~kg}$ and producing $45 \mathrm{~kg}$ of $3.5 \% \mathrm{FCM}$ (NRC, 2001). Cows were milked 3 times daily at approximately 8 -h intervals and received bovine somatotropin (bST; Posilac, $500 \mathrm{mg}$; Elanco Animal Health, Indianapolis, IN) starting at approximately $63 \mathrm{~d}$ postpartum and continuing every $14 \mathrm{~d}$ until cows were dried off.

Cows were submitted to a Presynch-Ovsynch protocol for first service AI as described by Navanukraw et al. (2004). Briefly, cows received 2 intramuscular injections of $\mathrm{PGF}_{2 \alpha}$ (25 mg i.m. of Dinoprost tromethamine, Lutalyse; Pfizer Animal Health, New York, NY) $14 \mathrm{~d}$ apart at $39 \pm 3$ and $53 \pm 3$ DIM. Cows detected in estrus based on tail chalk removal conducted daily after the second $\mathrm{PGF}_{2 \alpha}$ injection of the presynchronization protocol were inseminated by professional AI technicians, whereas cows not detected in estrus within $14 \mathrm{~d}$ of the second $\mathrm{PGF}_{2 \alpha}$ injection initiated an Ovsynch-56 protocol as described by Brusveen et al. (2008). Cows enrolled in the Ovsynch-56 protocol received the first GnRH injection $(100 \mu \mathrm{g}$ i.m. of Gonadorelin diacetate tetrahydrate, Fertagyl; Intervet Animal Health, Millsboro, DE), an injection of $\mathrm{PGF}_{2 \alpha} 7 \mathrm{~d}$ later $(25 \mathrm{mg}$ i.m. of Dinoprost tromethamine), and the second GnRH injection $(100 \mu \mathrm{g}$ i.m. of gonadorelin diacetate tetrahydrate) $56 \mathrm{~h}$ after the $\mathrm{PGF}_{2 \alpha}$ injection. Cows received a TAI approximately 16 to $20 \mathrm{~h}$ after the second $\mathrm{GnRH}$ injection.

\section{Experimental Treatments}

After first service and until cows were enrolled in the resynchronization of ovulation treatments, cows were detected in estrus based on removed tail chalk and were inseminated as described previously. Each week, a cohort of cows at various DIM and having at least 1 AI service were blocked by parity and assigned to a $2 \times 2$ factorial design $25 \pm 3 \mathrm{~d}$ after AI (if not detected in estrus and inseminated) to test the main effects of day of initiation of the resynchronization protocol after AI (32 \pm 3 vs. $39 \pm 3 \mathrm{~d}$ ) and the effect of presynchronization with GnRH 7 d before initiation of resynchronization. Throughout the experiment, cows detected in estrus either before or after enrollment were inseminated. The number of cows enrolled into the 4 resynchronization treatments and the number of cows receiving TAI for each treatment differed because the interval from AI to initiation of resynchronization differed among treatments. As the interval from AI to initiation of resynchronization increased, the number of cows inseminated at a detected estrus increased and the number of cows completing the protocols and receiving TAI decreased (Table 1).

Four experimental treatments resulted from the $2 \times$ 2 factorial design (Figure 1) as follows: (1) GGPG32 cows $(\mathrm{n}=384)$ were presynchronized with $\mathrm{GnRH}$ $(100 \mu \mathrm{g})$ at $25 \pm 3 \mathrm{~d}$ after AI, nonpregnancy diagnosis was performed $32 \pm 3 \mathrm{~d}$ after $\mathrm{AI}$, and nonpregnant cows were submitted for resynchronization of ovulation with the Ovsynch-56 protocol ( $\mathrm{GnRH}$ treatment, $\mathrm{PGF}_{2 \alpha}$ treatment $7 \mathrm{~d}$ later, and $\mathrm{GnRH}$ treatment $56 \mathrm{~h}$ later) and received TAI 16 to $20 \mathrm{~h}$ later $(\mathrm{n}=335)$; $(2)$ GPG32 cows $(\mathrm{n}=378)$ were diagnosed for pregnancy $32 \pm 3 \mathrm{~d}$ after AI and nonpregnant cows were submitted to the Ovsynch-56 protocol to receive their next TAI ( $\mathrm{n}=289)$; (3) GGPG39 cows $(\mathrm{n}=356)$ were submitted for nonpregnancy diagnosis $32 \pm 3 \mathrm{~d}$ after AI and nonpregnant cows were presynchronized with GnRH $(100 \mu \mathrm{g})$ and $7 \mathrm{~d}$ later were submitted to the Ovsynch-56 protocol to receive their next TAI $(\mathrm{n}=$ 269); and (4) GPG39 cows $(\mathrm{n}=338)$ were diagnosed for pregnancy $32 \pm 3 \mathrm{~d}$ after $\mathrm{AI}$ and nonpregnant cows 
Table 1. Number of cows enrolled (n) in each of 4 resynchronization treatments based on method of insemination after enrollment

\begin{tabular}{|c|c|c|c|c|c|}
\hline \multirow[b]{2}{*}{ Item } & \multirow[b]{2}{*}{$\mathrm{n}$} & \multicolumn{4}{|c|}{ Treatment $^{1}$} \\
\hline & & GGPG32 & GPG32 & GGPG39 & GPG39 \\
\hline Enrolled & 3,447 & - & - & - & - \\
\hline Pregnant & 1,466 & - & - & - & - \\
\hline Nonpregnant & 1,981 & 435 & 429 & 411 & 396 \\
\hline Out of study & 525 & 51 & 51 & 55 & 58 \\
\hline $\mathrm{ED}^{2}$ & 344 & 49 & 89 & 87 & 119 \\
\hline $\mathrm{TAI}^{3}$ & 1,112 & 335 & 289 & 269 & 219 \\
\hline Included in study & 1,456 & 384 & 378 & 356 & 338 \\
\hline \multicolumn{6}{|c|}{$\begin{array}{l}{ }^{1} \text { GPG32 }=\text { Ovsynch [GnRH treatment, } \text { PGF }_{2 \alpha} \text { treatment } 7 \text { d later, GnRH treatment } 56 \mathrm{~h} \text { later, and timed A } \\
\text { (TAI) } 16 \mathrm{~h} \text { later] initiated } 32 \pm 3 \mathrm{~d} \text { after AI; GGPG32 = presynchronization with } 100 \mu \mathrm{g} \text { of } \mathrm{GnRH} 25 \pm \\
\mathrm{d} \text { after AI and Ovsynch initiated } 32 \pm 3 \mathrm{~d} \text { after AI at nonpregnancy diagnosis; GPG39 }=\text { Ovsynch initiated } \\
39 \pm 3 \mathrm{~d} \text { after AI; GGPG39= presynchronization with } 100 \mu \mathrm{g} \text { of GnRH } 32 \pm 3 \mathrm{~d} \text { after AI at nonpregnancy } \\
\text { diagnosis and Ovsynch initiated } 39 \pm 3 \mathrm{~d} \text { after AI. }\end{array}$} \\
\hline \multicolumn{6}{|c|}{$\begin{array}{l}{ }^{2} \text { Cows detected in estrus (ED) based on removed tail chalk after enrollment into a treatment but before init } \\
\text { tion of the resynchronization protocol were inseminated at detected estrus. }\end{array}$} \\
\hline
\end{tabular}

were submitted $7 \mathrm{~d}$ later to the Ovsynch-56 protocol to receive their next TAI $(\mathrm{n}=219)$. Cows failing to conceive after a resynchronized TAI service or AI after a detected estrus continued to be reenrolled at random to the experimental treatments until they either conceived, were coded as "do not breed," or left the herd. Overall, 1,466 cows were diagnosed pregnant at the preenrollment AI pregnancy diagnosis and were removed from the experiment because enrollment of cows into the experiment was performed regardless of pregnancy status. A total of 1,981 AI [1,112 cows receiving TAI +344 cows detected in estrus $($ ED $)+525$ cows that were removed from the experiment] from 1,649 lactating Holstein cows were recorded.

Data from 344 inseminations in 313 cows were removed from the analyses due to insemination after detection of estrus (GGPG32 cows: $\mathrm{n}=49$; GPG32 cows: $\mathrm{n}=89$; GGPG39 cows: $\mathrm{n}=87$; and GPG39 cows: $\mathrm{n}=$ 119) because visual detection of estrus was performed every morning on this farm based on removed tail chalk. Analysis of pregnancy outcomes after TAI (Table 1) was performed on data from 1,112 inseminations in 857 cows (GGPG32 cows: $\mathrm{n}=335$; GPG32 cows: $\mathrm{n}=289$; GGPG39 cows: $\mathrm{n}=269$; and GPG39 cows: $\mathrm{n}=219$ ).

Data from 525 TAI in 479 cows were removed from the analysis (Table 1) due to factors that could not be controlled, including (1) culled from the herd before the pregnancy diagnosis after TAI (i.e., dead, sold, or called "do not breed" by herd personnel), (2) cows that did not complete the resynchronization protocol because they had a uterine infection or a nonviable embryo at the pregnancy diagnosis after enrollment, (3) cows that were not located on the farm during any of the scheduled injections of the resynchronization protocol, and
(4) cows that had 9 or more inseminations. Cows (n $=53$ ) that had 9 or more inseminations were excluded from the analysis because they had P/AI of $6 \%(3 / 53)$ compared with $35 \%(392 / 1,112)$ for cows with 2 to 8 inseminations.

\section{Pregnancy Diagnosis, Ovarian Ultrasonography, and Ovulatory Responses}

Pregnancy diagnosis $32 \pm 3 \mathrm{~d}$ after AI and ovarian ultrasonography was performed using a portable scanner (Ibex Pro; E. I. Medical Imaging, Loveland, $\mathrm{CO})$ fitted with a $7.5-\mathrm{MHz}$ linear-array transducer. A positive pregnancy diagnosis was based on the presence of a CL and an embryo with a heartbeat. At 64 $\pm 3 \mathrm{~d}$ after AI, pregnancy status was reconfirmed in cows diagnosed pregnant $32 \pm 3 \mathrm{~d}$ after AI based on transrectal palpation of uterine contents by the herd veterinarian. A cow was considered to have undergone pregnancy loss if she was confirmed pregnant at the initial pregnancy diagnosis and was diagnosed nonpregnant at the pregnancy reconfirmation $64 \pm 3 \mathrm{~d}$ after AI or if she was detected in estrus and inseminated during the same time period.

In a subgroup of cows $(\mathrm{n}=400)$ from all treatments (GGPG32: $\mathrm{n}=112$, GPG32: $\mathrm{n}=95$, GGPG39: $\mathrm{n}=$ 106, and GPG39: $\mathrm{n}=87$ ), the number and size of all ovarian structures $>8 \mathrm{~mm}$ in diameter was recorded at the first $\mathrm{GnRH}$ injection of the resynchronization protocols $(\mathbf{G 1})$ and $7 \mathrm{~d}$ later at the $\mathrm{PGF}_{2 \alpha}$ injection to determine ovulatory response to G1. Follicle and CL diameters were estimated and recorded based on on-screen background gridlines consisting of squares with $10 \times 10$-mm sides. A cow was considered to have 


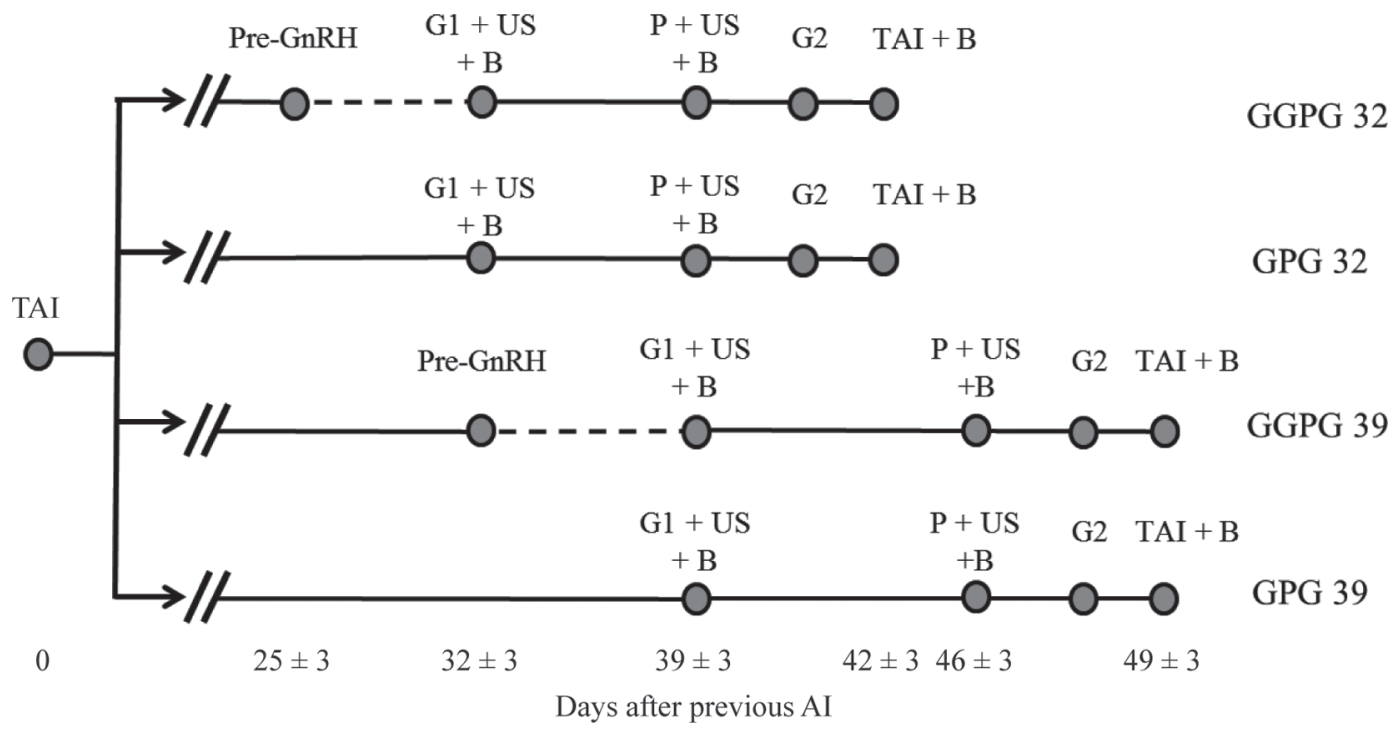

Figure 1. Resynchronization protocols for cows assigned randomly to initiation of resynchronization $32 \pm 3 \mathrm{~d}$ after previous AI with presynchronization with GnRH (GGPG32), initiation of resynchronization $32 \pm 3$ d after previous AI with no presynchronization with GnRH (GPG32), initiation of resynchronization $39 \pm 3$ d after previous AI with presynchronization with GnRH (GGPG39), and initiation of resynchronization $39 \pm 3$ d after previous AI with no presynchronization with GnRH (GPG39) for second and subsequent postpartum timed AI (TAI) services. Cows received an initial TAI after synchronization of ovulation by Ovsynch or after estrus detection. Every week, cohorts of cows were randomly assigned to 1 of 4 treatments for resynchronization of ovulation and TAI for second and greater services. Blood samples (B) were collected at the time of the first GnRH treatment (G1) to determine progesterone concentrations from all cows. In a subgroup of cows, ovarian ultrasonography (US) was performed at G1 and $\mathrm{PGF}_{2 \alpha}$ of resynchronization and blood samples were collected at G1 to determine progesterone concentrations and then at the time of $\mathrm{PGF}_{2 \alpha}$ and $\mathrm{TAI}$ to determine luteal regression after $\mathrm{PGF}_{2 \alpha}$ administration. $\mathrm{G} 2=$ second $\mathrm{GnRH}$ treatment; $\mathrm{P}=\mathrm{PGF} 2 \alpha$.

ovulated to G1 when one or more follicles $\geq 10 \mathrm{~mm}$ were recorded at the time of G1 and the presence of a new CL was confirmed in the same location $7 \mathrm{~d}$ later at the time of the $\mathrm{PGF}_{2 \alpha}$ injection.

\section{Blood Sampling and Progesterone Analysis}

Blood samples $(\mathrm{n}=1,107)$ were collected via venipuncture of the median coccygeal vein or artery into 10$\mathrm{mL}$ evacuated serum collection tubes (Vacutainer; BD, Franklin Lakes, NJ) at G1 to determine progesterone (P4) concentration. For the same subgroup of cows, blood samples were collected at the $\mathrm{PGF}_{2 \alpha}$ injection of the resynchronization protocols and $3 \mathrm{~d}$ later at TAI to assess luteal regression after treatment with $\mathrm{PGF}_{2 \alpha}$. Luteal regression was defined as a decrease in $\mathrm{P} 4$ concentration from $\geq 1.0 \mathrm{ng} / \mathrm{mL}$ at the $\mathrm{PGF}_{2 \alpha}$ injection to $<0.3 \mathrm{ng} / \mathrm{mL}$ at TAI. Blood samples were centrifuged $\left(2,000 \times g\right.$ for $20 \mathrm{~min}$ at $\left.4^{\circ} \mathrm{C}\right)$, and serum was stored in 2-mL Safe-Lock Tubes (Eppendorf AG, Hamburg, Germany) at $-20^{\circ} \mathrm{C}$ until assayed for $\mathrm{P} 4$. The concentration of $\mathrm{P} 4$ was determined using a solid-phase, noextraction RIA (Coat-A-Count; Diagnostic Products Corp., Los Angeles, CA). The average sensitivity for the $6 \mathrm{P} 4$ assays was $0.018 \mathrm{ng} / \mathrm{mL}$. The intraassay and interassay coefficients of variation were 2.16 and $2.58 \%$, respectively.

\section{Statistical Analyses}

The experimental design was a complete randomized block design with parity (primiparous vs. multiparous) as the blocking factor, whereas the arrangement of treatments was a $2 \times 2$ factorial consisting of the main effects of presynchronization with GnRH and day of initiation of the resynchronization protocol (32 vs. 39). Binary response data (P/AI, pregnancy loss, ovulatory response to $\mathrm{GnRH}$, and luteal regression after $\mathrm{PGF}_{2 \alpha}$ ) were analyzed by logistic regression using PROC GLIMMIX of SAS (version 9.2; SAS Institute Inc., Cary, NC). For P/AI, $32 \pm 3$ and $64 \pm 3 \mathrm{~d}$ after TAI and pregnancy loss, the initial model included parity (primiparous vs. multiparous), day of initiation of resynchronization (32 vs. 39), presynchronization with GnRH (yes vs. no), AI service number (2 to 8 ), AI technician, AI service sire, and all 2-way interactions. Model selection was performed by finding the model with the lowest value for the Akaike information criterion using a backward elimination procedure that removed all variables with $P$ $>0.10$ from the model. Both treatment and parity were forced to remain in each model. Parity was kept in the final models because it was used as a blocking factor for randomization of cows to treatments. All final models used to analyze P/AI and pregnancy loss included the fixed effects of day of initiation of resynchronization, 
presynchronization with GnRH, AI service number, and all 2-way interactions.

Data were collected from the subgroup of cows sampled for P4 concentration at G1 of the resynchronization protocols on $\mathrm{P} / \mathrm{AI}$; cows were distributed into 9 categories of $0.5 \mathrm{ng} / \mathrm{mL}$ increments (from serum P4 concentration equal to 0.00 to $\geq 4.00 \mathrm{ng} / \mathrm{mL}$ ). Differences in the proportion of cows within each $\mathrm{P} 4$ concentration category were analyzed by logistic regression using PROC LOGISTIC of SAS. This same procedure was used to evaluate differences in expression of estrus after their initial AI. The effect of $\mathrm{P} 4$ on $\mathrm{P} / \mathrm{AI}$ was assessed by logistic regression using PROC GLIMMIX of SAS with a model that only contained the variable $\mathrm{P} 4$ concentration as a fixed effect.

Data from the subgroup of cows with available information for $\mathrm{P} 4$ concentration at $\mathrm{G} 1, \mathrm{PGF}_{2 \alpha}$, and TAI of all resynchronization treatments as well as ovulatory response to G1 were used to evaluate and compare the percentage of cows with their estrous cycle synchronized (overall response to the protocol injections) and P/AI after completion of treatments. Both the proportion of cows and P/AI were calculated and compared for the different intermediate classification groups created sequentially as follows: cows with low versus high $\mathrm{P} 4$ at the time of the $\mathrm{PGF}_{2 \alpha}$ injection, low versus high $\mathrm{P} 4$ at TAI, and whether or not cows synchronized to the protocols (synchronized vs. nonsynchronized). Statistical differences for the proportion of cows and P/AI for the different groups were analyzed by logistic regression either using PROC GLIMMIX or PROC LOGISTIC of SAS.

A significant difference between the levels of a classification variable was considered when $P<0.05$, whereas differences with $P \geq 0.05$ and $P \leq 0.10$ was considered a statistical tendency. The outcomes are presented as arithmetic means obtained using PROC FREQ or PROC MEANS of SAS, whereas least squares means estimates and standard error of the mean $( \pm$ SEM $)$ are also reported in the text and in the tables.

\section{RESULTS AND DISCUSSION}

\section{Effect of Treatment on P/AI and Pregnancy Loss}

In the present experiment, cows presynchronized with GnRH $7 \mathrm{~d}$ before initiation of resynchronization had more $\mathrm{P} / \mathrm{AI}$ at both $32 \mathrm{~d}(P=0.03)$ and $64 \mathrm{~d}(P=$ 0.01 ) after AI compared with cows not presynchronized with GnRH. This observation supports our first hypothesis that presynchronizing the estrous cycle before initiation of a resynchronization of ovulation protocol would increase fertility of resynchronized dairy cows and agrees with several recent studies. Presynchroniza- tion with GnRH 7 d before initiation of a resynchronization protocol $39 \mathrm{~d}$ after $\mathrm{AI}$ increased $\mathrm{P} / \mathrm{AI}$ by about 8 percentage points compared with control cows (Dewey et al., 2010), and presynchronization with either GnRH or human chorionic gonadotropin $7 \mathrm{~d}$ before initiation of resynchronization $25 \mathrm{~d}$ after $\mathrm{AI}$ increased $\mathrm{P} / \mathrm{AI}$ by about 7 percentage points compared with cows that were not presynchronized (Giordano et al., 2012a). By contrast, Alkar et al. (2011) did not detect an increase in $\mathrm{P} / \mathrm{AI}$ for cows presynchronized with $\mathrm{GnRH}$ before initiation of a resynchronization protocol. One explanation for the lack of an effect of $\mathrm{GnRH}$ on fertility in that experiment is that cows were treated with GnRH $28 \pm 3 \mathrm{~d}$ after AI. Assuming a 23-d interovulatory interval for lactating dairy cows (Sartori et al., 2004), the majority of cows would be early in their estrous cycle (i.e., before $\mathrm{d} 5$ ) and may not have responded to the GnRH injection by ovulating a follicle.

Our second hypothesis was that cows initiating the resynchronization protocol $32 \mathrm{~d}$ after AI would have better fertility compared with cows starting the resynchronization protocol $39 \mathrm{~d}$ after AI. In the present experiment, day of initiation of resynchronization did not affect $\mathrm{P} / \mathrm{AI}$ and no interaction was detected $(P$ $=0.55)$ between the effect of presynchronization with GnRH and day of initiation of resynchronization. Considering that cows have a 23-d interovulatory interval (Sartori et al., 2004) and, therefore, should have a better response to the first GnRH injection of Ovsynch when administered between d 5 and 9 of the estrous cycle (Vasconcelos et al., 1999), we hypothesized that cows initiating the resynchronization protocols $32 \mathrm{~d}$ after previous AI would have an increased ovulatory response to G1, thereby increasing fertility by improving synchrony to the protocol. Results from the present study, however, showed no difference in P/AI for cows initiating the resynchronization protocol $32 \pm 3$ or 39 $\pm 3 \mathrm{~d}$ after previous $\mathrm{AI}$ and we therefore rejected our second hypothesis.

Cows initiating resynchronization $32 \mathrm{~d}$ after AI would result in a greater pregnancy rate over time compared with cows initiating resynchronization $39 \mathrm{~d}$ after AI due to a decreased interbreeding interval because timing of initiation of resynchronization did not affect P/ AI. These results support the notion that the interval from a prior $\mathrm{AI}$ is not a reliable predictor of stage of the estrous cycle at initiation of resynchronization (Silva et al., 2007; Giordano et al., 2012a,c). This is likely due to some cows that are not synchronized at the prior AI, variation in cycle length among cows, and the occurrence of early pregnancy loss and short luteal phases (Dewey et al., 2010; Giordano et al., 2012a). Thus, methods to presynchronize the estrous cycle before initiation of resynchronization need to be developed and 
Table 2. Effect of resynchronization treatment on pregnancies per AI (P/AI) 32 and $64 \mathrm{~d}$ after timed AI (TAI) and pregnancy loss from 32 to 64 d after

\begin{tabular}{|c|c|c|c|c|c|c|c|}
\hline \multirow[b]{2}{*}{ Item } & \multicolumn{4}{|c|}{ Treatment $^{1}$} & \multicolumn{3}{|c|}{$P$-value } \\
\hline & GGPG32 & GPG32 & GGPG39 & GPG39 & Day & GnRH & Interaction \\
\hline $\mathrm{LSM} \pm \mathrm{SEM}$ & $33.2 \pm 0.03$ & $25.8 \pm 0.03$ & $37.9 \pm 0.03$ & $26.7 \pm 0.03$ & 0.33 & 0.03 & 0.55 \\
\hline P/AI, 64 d [\% (no./total no.)] & $34.6(115 / 332)$ & $30.5(87 / 285)$ & $38.5(102 / 265)$ & $32.3(70 / 217)$ & & & \\
\hline $\mathrm{LSM} \pm \mathrm{SEM}$ & $31.6 \pm 0.03$ & $22.6 \pm 0.03$ & $35.7 \pm 0.03$ & $24.6 \pm 0.03$ & 0.27 & 0.01 & 0.77 \\
\hline Loss, 32 to 64 d [\% (no./total no.)] & $4.9(6 / 121)$ & $6.5(6 / 93)$ & $4.7(5 / 107)$ & $4.1(3 / 73)$ & & & \\
\hline
\end{tabular}

${ }^{1}$ GPG32 = Ovsynch $(\mathrm{GnRH}$ treatment. PGF 2 treatment 7 d later, GnRH treatment $56 \mathrm{~h}$ later, and TAI $16 \mathrm{~h}$ later $)$ initiated $32 \pm 3 \mathrm{~d}$ after AI; GGPG32 = presynchronization with $100 \mu \mathrm{g}$ of GnRH $25 \pm 3 \mathrm{~d}$ after AI and Ovsynch initiated $32 \pm 3 \mathrm{~d}$ after AI at nonpregnancy diagnosis; GPG39 = Ovsynch initiated $39 \pm 3 \mathrm{~d}$ after AI; GGPG39 = presynchronization with $100 \mu \mathrm{g}$ of GnRH $32 \pm 3 \mathrm{~d}$ after AI at nonpregnancy diagnosis and Ovsynch initiated $39 \pm 3 \mathrm{~d}$ after AI.

refined to improve fertility to resynchronized inseminations.

No effect was observed of parity on P/AI to resynchronized services in the present experiment, and this result was in agreement with other experiments (Galvão et al., 2007; Brusveen et al., 2008; Silva et al., 2009). Pregnancy loss from 32 to $39 \mathrm{~d}$ after TAI was not affected by any of the variables in the statistical model and averaged 5\% across the 4 treatments (Table 2). The lack of effect of day of initiation of resynchronization and presynchronization with GnRH on pregnancy loss was not surprising because most studies comparing TAI programs after resynchronization have reported similar results (Sterry et al., 2006a; Silva et al., 2009; Thompson et al., 2010).

Data from cows that were inseminated to detected estrus were excluded from the analysis for TAI because professional AI technicians performed detection of estrus once daily based on removed tail chalk. The overall $\mathrm{P} / \mathrm{AI}$ for $\mathrm{ED}$ cows did not differ $(P=0.58)$ from that of cows receiving TAI (38 vs. $37 \%$ for ED vs. TAI, respectively). It is important to note that this does not reflect the fertility of all cows in this herd that were detected in estrus but only the fertility of cows receiving AI after detection of estrus that were enrolled for 1 of the 4 treatments for resynchronization at $25 \pm 3 \mathrm{~d}$ after AI.

An effect $(P=0.0001)$ of AI number was observed in the present experiment (Figure 2) in which $\mathrm{P} / \mathrm{AI}$ decreased by about 15 percentage points for cows receiving their second to fourth AI service and then remained constant for cows receiving their fourth to eighth AI service. Cows $(n=53)$ that had 9 or more inseminations were excluded from the analysis because they had $\mathrm{P} / \mathrm{AI}$ of $6 \%(3 / 53)$ compared with $35 \%(392 / 1,112)$ for cows with 2 to 8 inseminations. No interaction of AI number with the effect of presynchronization with GnRH or day of initiating the resynchronization protocol was detected. We have reported an effect of insemination number in other resynchronization experi- ments that agree with the current results (Sterry et al., 2006a; Silva et al., 2007, 2009). Several experiments support that strategies to presynchronize cows submitted to a resynchronization protocol can increase fertility (Silva et al., 2007; Dewey et al., 2010; Giordano et al., 2012a,c), suggesting that part of the problem with resynchronized inseminations is that cows initiate the protocol at a suboptimal stage of the estrous cycle. Nonetheless, the effect of AI number on P/AI also supports the notion that a subpopulation of lower fertility cows accumulates as AI number increases within a herd. The effect of AI number is reflected in the difference between the observed and adjusted (i.e., LSM) percentages presented in Table 2 .

\section{Effect of P4 During the Resynchronization Protocols}

Overall, cows with low $\mathrm{P} 4$ at $\mathrm{G} 1$ had fewer $(P=$ $0.02) \mathrm{P} / \mathrm{AI}$ compared with cows with high $\mathrm{P} 4$ at G1 [31.8\% (111/349) vs. $38.6 \%(293 / 758)]$, respectively, in agreement with data from other studies (Silva et al., 2007; Giordano et al., 2012c). This observation was the idea underlying the concept of presynchronization with GnRH 7 d before initiation of resynchronization. Although we detected an increase in P/AI for cows presynchronized with $\mathrm{GnRH}$, serum $\mathrm{P} 4$ concentration at G1 did not differ among the 4 treatments. Mean P4 concentrations at G1 were 2.27, 2.43, 2.74, and $2.63 \mathrm{ng} /$ mL for GGPG32 $(\mathrm{n}=335)$, GPG32 $(\mathrm{n}=286)$, GGPG39 $(\mathrm{n}=269)$, and GPG39 $(\mathrm{n}=217)$, respectively. Overall, $70.5 \%(426 / 604)$ of cows presynchronized with $\mathrm{GnRH}$ $7 \mathrm{~d}$ before initiation of resynchronization (GGPG; $\mathrm{n}=$ 604) had high P4 concentration at G1, which did not differ $(P=0.15)$ from cows that were not presynchronized (GPG; $\mathrm{n}=503)$, with $66 \%(332 / 503)$ of those cows having high $\mathrm{P} 4$ at $\mathrm{G} 1$. Mean P4 concentrations were 2.48 versus $2.51 \mathrm{ng} / \mathrm{mL}$ for GGPG $(\mathrm{n}=604)$ versus GPG ( $\mathrm{n}=503)$ cows, respectively. Although this observation did not agree with our preconceived notion 


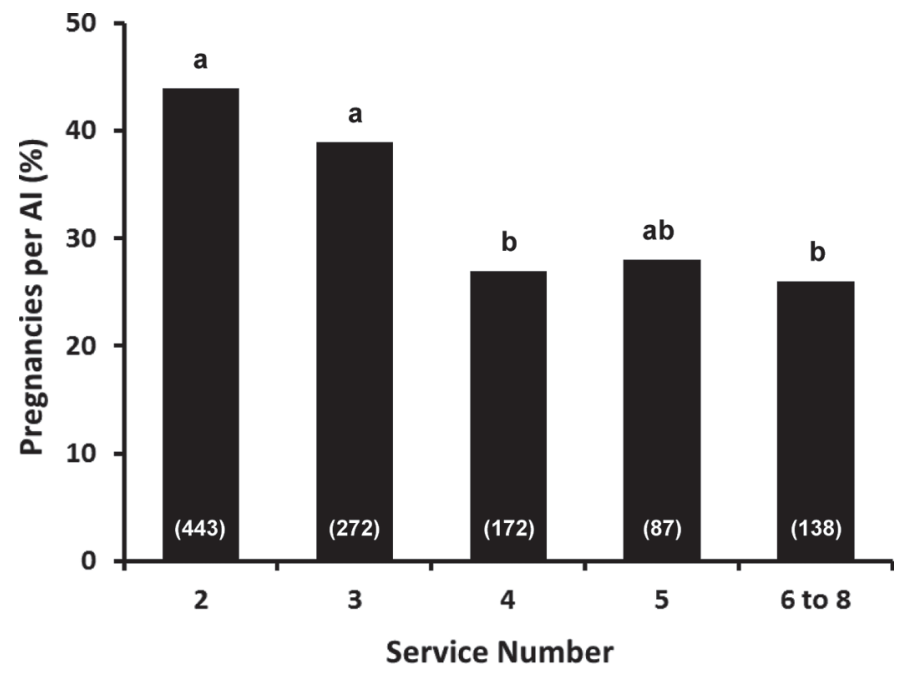

Figure 2. Pregnancies per $\mathrm{AI}(\mathrm{P} / \mathrm{AI})$ for cows resynchronized based on AI service number. Bars with different letters ( $\mathrm{a}$ and $\mathrm{b}$ ) differ $(P<0.05)$.

of the effect of the GGPG protocol on P4 concentrations at $\mathrm{G} 1$, it is in agreement with a similar experiment in which $\mathrm{P} 4$ at $\mathrm{G} 1$ did not differ between cows receiving similar GGPG and GPG protocols but initiated $7 \mathrm{~d}$ later compared with the prior AI (Dewey et al., 2010).

The lack of an effect of presynchronization with GnRH on P4 concentrations at G1 lead us to further explore P4 concentrations at G1. Cows were divided into $9 \mathrm{P} 4$ categories based on $0.5 \mathrm{ng} / \mathrm{mL}$ increments ranging from less than $0.5 \mathrm{ng} / \mathrm{mL}$ to greater or equal to $4.0 \mathrm{ng} / \mathrm{mL}$, as reported by Giordano et al. (2012c). When analyzed in this way, a greater proportion of GPG compared with GGPG cows were present at the lowest $\mathrm{P} 4$ category $(<0.5 \mathrm{ng} / \mathrm{mL})$, which was also associated with lower fertility (Figure 3). Thus, although presynchronization with $\mathrm{GnRH}$ did not increase the proportion of cows with high $\mathrm{P} 4(>1.0 \mathrm{ng} / \mathrm{mL})$ at $\mathrm{G} 1$, it did shift some cows from a low-P4 environment to an intermediate-P4 level with greater $\mathrm{P} / \mathrm{AI}$ (0.05 to $2.49 \mathrm{ng} / \mathrm{mL}$ ). This effect of presynchronization with GnRH $7 \mathrm{~d}$ before initiation of resynchronization, however, is less dramatic than that reported in the study of Giordano et al. (2012c) in which an Ovsynch protocol was used to presynchronize cows before initiation of resynchronization. Furthermore, it is unlikely that the shifting of cows among the $\mathrm{P} 4$ categories in the present experiment fully accounts for the increase in $\mathrm{P} / \mathrm{AI}$ observed in the present study.

The effect of treatment on $\mathrm{P} 4$ concentration at the $\mathrm{PGF}_{2 \alpha}$ injection of the resynchronization protocols was analyzed to further explore the mechanism by which presynchronization with GnRH increased P/AI. Presynchronization with $\mathrm{GnRH} 7 \mathrm{~d}$ before initiation of resynchronization affected $(P=0.007)$ the proportion of cows with high $\mathrm{P} 4(\geq 1.0 \mathrm{ng} / \mathrm{mL})$ at the $\mathrm{PGF}_{2 \alpha}$ injection of the resynchronization protocols. Overall, $80.0 \%$ (179/224) of GGPG cows had high P4 at $\mathrm{PGF}_{2 \alpha}$ compared with only $68.4 \%(132 / 193)$ of GPG cows. This observation agrees with other studies reporting a positive effect of $\mathrm{P} 4$ concentration at the $\mathrm{PGF}_{2 \alpha}$ injection of the Ovsynch protocol on fertility (Fricke et al., 2003; Navanukraw et al., 2004; Bello et al., 2006; Giordano et al., 2012c). Bello et al. (2006) found a correlation between the concentration of $\mathrm{P} 4$ at the $\mathrm{PGF}_{2 \alpha}$ injection of the Ovsynch protocol and probability of pregnancy
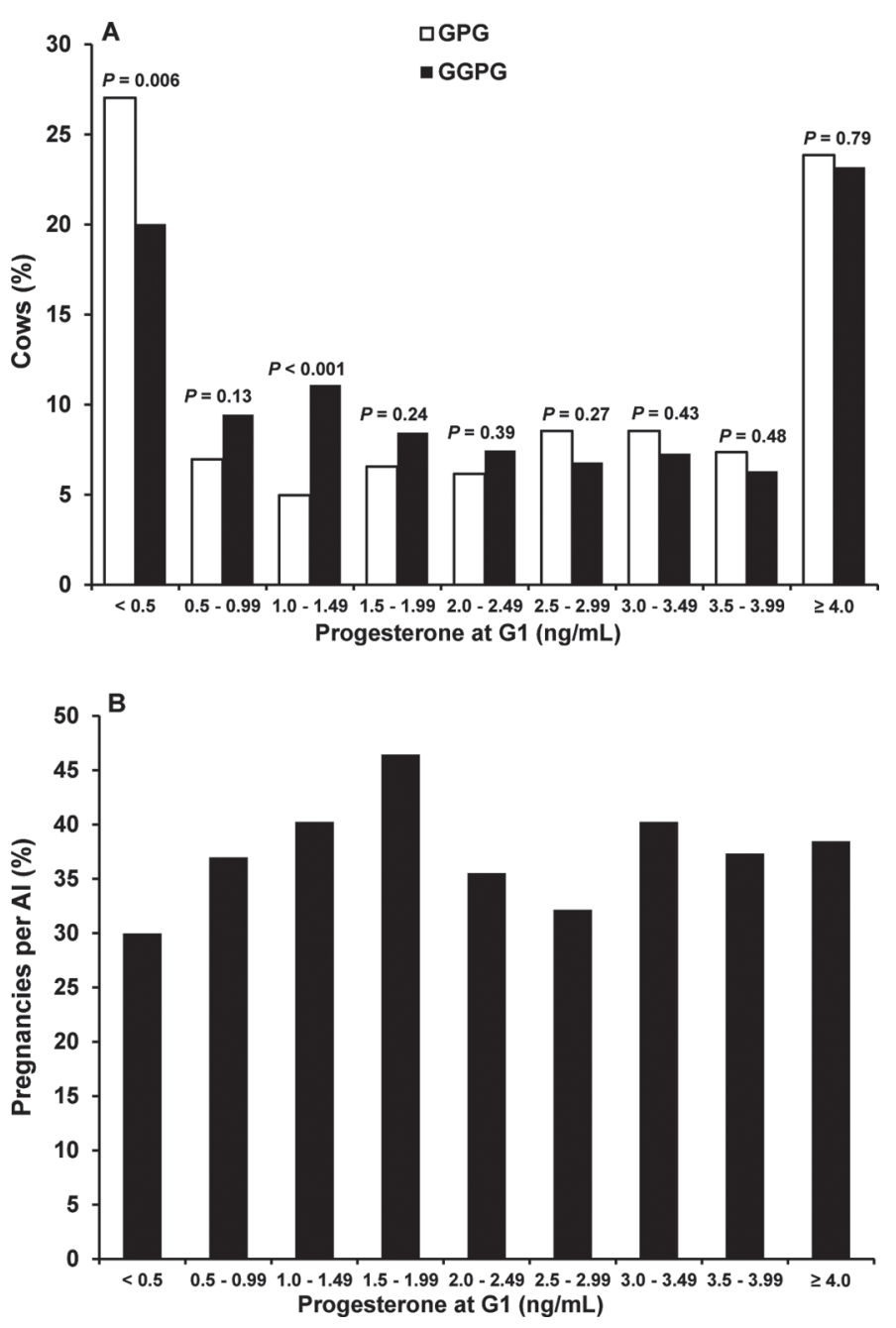

Figure 3. Distribution of cows according to progesterone (P4) concentration at the first GnRH injection before TAI (G1) of the resynchronization protocol with no presynchronization with GnRH $7 \mathrm{~d}$ before initiation of resynchronization (GPG) and with presynchronization with GnRH 7 d before initiation of resynchronization (GGPG) protocol (panel A), and pregnancies per AI (P/AI) for cows in the different $\mathrm{P} 4$ concentration groups at G1 before TAI in cows from both treatments (GPG and GGPG; panel B). Concentration groups vary by $0.5 \mathrm{ng} / \mathrm{mL}$ increments. $P$-values indicate treatment differences in the proportion of cows within a $\mathrm{P} 4$ concentration group. 
$35 \mathrm{~d}$ after AI. Among cows that had synchronized an ovulation in response to the protocol, $\mathrm{P} 4$ concentrations at the $\mathrm{PGF}_{2 \alpha}$ injection of the Ovsynch protocol were identified as a predictor of pregnancy $35 \mathrm{~d}$ after AI with an odds ratio of 1.7 . In addition, the predicted probability of pregnancy increased $(P=0.007)$ as concentrations of $\mathrm{P} 4$ at the $\mathrm{PGF}_{2 \alpha}$ injection of the Ovsynch protocol increased (Bello et al., 2006) making this parameter one of the best predictors of pregnancy for cows completing the synchronization protocol.

When the effect of day and parity were evaluated, mean $\mathrm{P} 4$ differed for cows initiating the resynchronization protocol 32 versus $39 \mathrm{~d}$ after AI $(P=0.009)$, but did not differ between primiparous versus multiparous cows. Mean P4 was 2.34 versus $2.69 \mathrm{ng} / \mathrm{mL}$ for cows initiating the resynchronization protocol $32 \mathrm{~d}(\mathrm{n}=621)$ versus $39 \mathrm{~d}(\mathrm{n}=486)$ after $\mathrm{AI}$ and 2.48 versus 2.51 $\mathrm{ng} / \mathrm{mL}$ for primiparous $(\mathrm{n}=557)$ versus multiparous $(\mathrm{n}=550)$ cows. Greater P4 concentrations for cows initiating the resynchronization protocol $39 \mathrm{~d}$ after AI could occur because, on average, cows were likely at a later stage of their estrous cycle and had older CL producing more $\mathrm{P} 4$ compared with cows initiating the resynchronization protocol $32 \mathrm{~d}$ after AI.

\section{Ovulatory Response to G1 and Luteal Regression After PGF $F_{2 \alpha}$}

Ovulatory response to G1 was affected by the day of initiation of resynchronization $(P=0.02)$ but was not affected by presynchronization with $\mathrm{GnRH}$, by parity, or any of the 2-way interactions in the statistical model. Overall, $53.0 \%(114 / 215)$ of cows initiating resynchronization $32 \mathrm{~d}$ after AI ovulated in response to G1 compared with only $41.0 \%$ (83/202) of cows initiating resynchronization $39 \mathrm{~d}$ after AI. When presynchronization with $\mathrm{GnRH}$ was removed from the statistical model and only the nonpresynchronized cows were compared, the pattern of ovulatory response was similar, with a $51.0 \%(51 / 100)$ ovulatory response to G1 for GPG32 cows compared with 41.9\% (39/93) for GPG39 cows.

Ovulatory response to G1 was similar for cows presynchronized with GnRH [47.8\% (107/224); GGPG] and those not presynchronized [46.6\% (90/193); GPG] and for primiparous [45.0\% (94/209)] compared with multiparous cows $(49.6 \%$; 103/208). Concentration of $\mathrm{P} 4$ at $\mathrm{G} 1$ affected $(P<0.0001)$ ovulatory response to G1. Cows were divided into high- versus low-P4 categories at $\mathrm{G} 1$ ( $\mathrm{P} 4$ cutoff $=0.5 \mathrm{ng} / \mathrm{mL})$ and cows with high $\mathrm{P} 4$ had fewer ovulations compared with cows with low P4 [40.9\% (132/323) vs. 69.1\% (65/94), respectively]. Several studies have reported an improvement in fertility in dairy cows with high P4 concentrations at G1 and in cows that ovulated to G1 (Vasconcelos et al., 1999;
Chebel et al., 2006; Stevenson et al., 2007). Surprisingly, the increase in $\mathrm{P} / \mathrm{AI}$ due to presynchronization with GnRH (and, consequently, with high P4 at G1) was not related to an increase in ovulatory response to G1. The suppressive effect of circulating $\mathrm{P} 4$ on $\mathrm{GnRH}$-induced LH secretion has been reported (Buttrey et al., 2010; Giordano et al., 2012b), and the mechanism seems to involve the negative feedback of high $\mathrm{P} 4$ on pituitary release of LH in both lactating dairy cows (Giordano et al., 2012b) and beef heifers (Dias et al., 2010).

Ovulatory response to $\mathrm{G} 1$ affected $(P=0.04)$ luteal regression after the $\mathrm{PGF}_{2 \alpha}$ treatment of the resynchronization protocols. Cows that failed to ovulate in response to G1 had a greater luteal regression rate compared with cows that ovulated $[87.3 \%(117 / 134)$ vs. $78.5 \%(139 / 177)]$. This likely occurred because cows that ovulated to G1 had a younger CL that was not yet fully responsive to $\mathrm{PGF}_{2 \alpha}$. The $\mathrm{P} 4$ cutoff concentration for luteal regression was chosen based on distribution of P/AI $32 \mathrm{~d}$ after TAI using different levels of P4 $72 \mathrm{~h}$ after $\mathrm{PGF}_{2 \alpha}$ administration as we have described previously (Giordano et al., 2012c; Figure 4). A value of 0.3 $\mathrm{ng} / \mathrm{mL}$ was selected based on the concentration of $\mathrm{P} 4$ at which $\mathrm{P} / \mathrm{AI}$ decreased by more than $50 \%$ compared with the lowest $\mathrm{P} / \mathrm{AI}$ in the $\mathrm{P} 4$ concentration levels with the greatest $\mathrm{P} / \mathrm{AI}$. This value is $0.1 \mathrm{ng} / \mathrm{mL}$ less than that used in 2 other experiments (Brusveen et al., 2009; Giordano et al., 2012c) because blood samples in the present experiment were collected at TAI rather than at the second GnRH injection of the Ovsynch protocol. Luteal regression $\left(\geq 1 \mathrm{ng} / \mathrm{mL}\right.$ at $\mathrm{PGF}_{2 \alpha}$ treatment and $<0.3 \mathrm{ng} / \mathrm{mL} 72 \mathrm{~h}$ after $\mathrm{PGF}_{2 \alpha}$ treatment) was not affected by day of initiation of the resynchronization protocol $[81.8 \%(135 / 165)$ vs. $82.9 \%(121 / 146)$ for 32 vs. $39 \mathrm{~d}$, respectively], or by presynchronization with GnRH [83.2\% (149/179) vs. 81.0\% (107/132) for GGPG vs. GPG cows, respectively].

\section{Synchronization Rate}

Because the effect of presynchronization with GnRH $7 \mathrm{~d}$ before initiation of resynchronization affected $\mathrm{P} /$ $\mathrm{AI}$, the effect of treatment on the synchronization rate for the resynchronization protocols and P/AI for synchronized and nonsynchronized cows were evaluated using a stepwise elimination procedure similar to that reported by Giordano et al. (2012c). Data from the same subgroup of cows $(\mathrm{n}=417)$ enrolled in the intensive ovary evaluation and blood sampling during the resynchronization protocols were used for this analysis. Data for these cows included complete information for $\mathrm{P} 4$ concentrations at $\mathrm{G} 1$, at the $\mathrm{PGF}_{2 \alpha}$ injection, and at TAI, as well as ovarian structures at G1 and at the $\mathrm{PGF}_{2 \alpha}$ injection of the resynchronization protocols. 


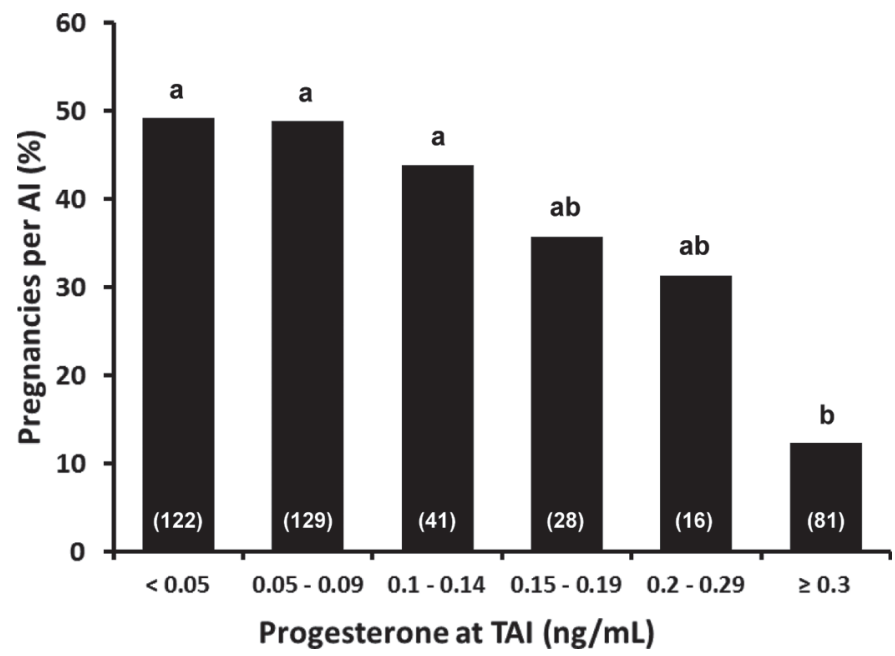

Figure 4. Effect of progesterone (P4) concentrations at timed AI (TAI) on pregnancies per AI (P/AI) $32 \mathrm{~d}$ after TAI for cows from all resynchronization treatments. Bars with different letters (a and b) differ $(P<0.05)$.

A greater $(P=0.007)$ percentage of GPG cows $(31.6 \%)$ had $\mathrm{P} 4$ concentration $<1.0 \mathrm{ng} / \mathrm{mL}$ at the $\mathrm{PGF}_{2 \alpha}$ injection of the resynchronization protocol compared with GGPG cows (20.0\%); however, P/AI for cows with low versus high $\mathrm{P} 4$ at the $\mathrm{PGF}_{2 \alpha}$ injection did not differ (Table 3). After eliminating cows with low $\mathrm{P} 4$ at the $\mathrm{PGF}_{2 \alpha}$ injection, the percentage of cows with $\mathrm{P} 4$ concentration $\geq 0.3 \mathrm{ng} / \mathrm{mL}$ at TAI did not differ between treatments (18.9 vs. $16.7 \%$ for GPG vs. GGPG cows, respectively), indicating that luteal regression was similar for both treatments. When $\mathrm{P} /$ AI was compared, no effect of treatment was observed, whereas cows with high P4 at TAI had lower fertility than cows with low P4 at TAI. The final step was to remove cows with $\mathrm{P} 4$ concentration $\geq 0.3 \mathrm{ng} / \mathrm{mL}$ at TAI to determine the effect of presynchronization with GnRH on overall synchrony to the protocols. A greater $(P=0.02)$ percentage of GGPG cows synchronized to the protocol (66.5\%) compared with GPG cows (55.4\%; Table 3). Cows that were not synchronized had few P/ AI for both treatments, whereas cows considered synchronized had more P/AI; however, P/AI did not differ between treatments for synchronized cows (Table 3).

We did not evaluate ovulation to the second $\mathrm{GnRH}$ injection in the present experiment so we could not assess complete synchronization to all injections of the resynchronization protocols. Based on the analysis of ovulatory response to G1 and luteal regression presented in Table 3, we conclude that the mechanism by which presynchronization improved fertility was to increase synchrony of the cows in response to the resynchronization protocol. The increased synchronization rate for GGPG cows is related to a greater proportion of cows that underwent complete luteal regression after the $\mathrm{PGF}_{2 \alpha}$ injection (Table 3) and may partially be related to a shifting in $\mathrm{P} 4$ concentration categories at G1 (Figure 3), thereby resulting in increased synchrony during the resynchronization protocol.

\section{CONCLUSIONS}

Presynchronization with GnRH 7 d before initiation of a resynchronization protocol for second and subsequent AI services improved fertility of lactating dairy cows compared with cows that were not presynchro-

Table 3. Main effect of presynchronization with $100 \mu \mathrm{g}$ of GnRH $7 \mathrm{~d}$ before initiation of resynchronization of ovulation on response to the resynchronization protocol

\begin{tabular}{|c|c|c|c|}
\hline \multirow[b]{2}{*}{ Item $^{2}$} & \multicolumn{2}{|c|}{ Treatment } & \multirow[b]{2}{*}{$P$-value } \\
\hline & $\begin{array}{c}\text { GPG } \\
{[\% \text { (no./total no.) }]}\end{array}$ & $\begin{array}{c}\text { GGPG } \\
{[\% \text { (no./total no.) }]}\end{array}$ & \\
\hline \multicolumn{4}{|l|}{$\mathrm{P} 4$ concentration at time of $\mathrm{PGF}_{2 \alpha}$} \\
\hline Cows with $\mathrm{P} 4$ concentration $<1 \mathrm{ng} / \mathrm{mL}$ & $31.6(61 / 193)$ & $20.0(45 / 224)$ & 0.007 \\
\hline $\mathrm{P} / \mathrm{AI}$ for cows with $\mathrm{P} 4$ concentration $<1 \mathrm{ng} / \mathrm{mL}$ & $32.8(20 / 61)$ & $26.7(12 / 45)$ & 0.53 \\
\hline $\mathrm{P} / \mathrm{AI}$ for cows with $\mathrm{P} 4$ concentration $\geq 1 \mathrm{ng} / \mathrm{mL}$ & $41.6(55 / 132)$ & $44.1(79 / 179)$ & 0.63 \\
\hline \multicolumn{4}{|l|}{$\mathrm{P} 4$ concentration at TAI } \\
\hline Cows with $\mathrm{P} 4$ concentration $\geq 0.3 \mathrm{ng} / \mathrm{mL}$ & $18.9(25 / 132)$ & $16.7(30 / 179)$ & 0.60 \\
\hline $\mathrm{P} / \mathrm{AI}$ for cows with $\mathrm{P} 4$ concentration $\geq 0.3 \mathrm{ng} / \mathrm{mL}$ & $8.0(2 / 25)$ & $13.3(4 / 30)$ & 0.97 \\
\hline $\mathrm{P} / \mathrm{AI}$ for cows with $\mathrm{P} 4$ concentration $<0.3 \mathrm{ng} / \mathrm{mL}$ & $49.5(53 / 107)$ & $50.3(75 / 149)$ & 0.86 \\
\hline \multicolumn{4}{|l|}{ Synchronization rate } \\
\hline Synchronized cows & $55.4(107 / 193)$ & $66.5(149 / 224)$ & 0.02 \\
\hline $\mathrm{P} / \mathrm{AI}$, not synchronized & $25.6(22 / 86)$ & $21.3(16 / 75)$ & 0.86 \\
\hline $\mathrm{P} / \mathrm{AI}$, synchronized & $49.6(53 / 107)$ & $50.3(75 / 149)$ & 0.52 \\
\hline
\end{tabular}

${ }^{1}$ Cows received a hormonal protocol $\left[\mathrm{GnRH}\right.$ treatment, $\mathrm{PGF}_{2 \alpha}$ treatment $7 \mathrm{~d}$ later, GnRH treatment $56 \mathrm{~h}$ later, and timed AI (TAI) $16 \mathrm{~h}$ later] for resynchronization of ovulation (GPG) or were presynchronized with $100 \mu \mathrm{g}$ of GnRH $7 \mathrm{~d}$ before initiation of an Ovsynch protocol for resynchronization of ovulation (GGPG).

${ }^{2} \mathrm{P} 4=$ progesterone; $\mathrm{P} / \mathrm{AI}=$ pregnancy per $\mathrm{AI}$. 
nized, whereas no difference in fertility was observed for cows initiating the resynchronization protocol 32 \pm 3 versus $39 \pm 3 \mathrm{~d}$ after AI. Contrary to what we expected, no difference was observed in the proportion of cows with high $\mathrm{P} 4$ at the first GnRH injection of the resynchronization protocols, but cows presynchronized with GnRH had greater synchrony to the protocol based on shifting cows to intermediate levels of P4. In the resynchronization scenarios compared in this experiment, initiating resynchronization $32 \mathrm{~d}$ after AI would result in a greater 21-d pregnancy rate compared with initiating resynchronization $39 \mathrm{~d}$ after AI because the interval between inseminations would decrease from 49 to $42 \mathrm{~d}$, on average. Future research evaluating simple protocols with a shorter interval between inseminations and evaluating how to achieve better synchrony during the protocols is warranted to further improve fertility to resynchronization protocols in lactating dairy cows.

\section{ACKNOWLEDGMENTS}

The authors thank Rosendale Dairy Inc. (Pickett, WI) and their staff for the use of their cows and facilities for this experiment.

\section{REFERENCES}

Alkar, A., A. Tibary, J. R. Wenz, R. L. Nebel, and R. Kasimanickam. 2011. Presynchronization with GnRH 7 days prior to resynchronization with CO-Synch did not improve pregnancy rate in lactating dairy cows. Theriogenology 76:1036-1041.

Bartolome, J. A., F. T. Silvestre, S. Kamimura, A. C. M. Arteche, P. Melendez, D. Kelbert, J. McHale, K. Swift, L. F. Archbald, and W. W. Thatcher. 2005. Resynchronization of ovulation and timed insemination in lactating dairy cows: I: Use of the Ovsynch and Heatsynch protocols after non-pregnancy diagnosis by ultrasonography. Theriogenology 63:1617-1627.

Bello, N. M., J. P. Steibel, and J. R. Pursley. 2006. Optimizing ovulation to first GnRH improved outcomes to each hormonal injection of Ovsynch in lactating dairy cows. J. Dairy Sci. 89:3413-3424.

Brusveen, D. J., A. P. Cunha, C. D. Silva, P. M. Cunha, R. A. Sterry, E. P. Silva, J. N. Guenther, and M. C. Wiltbank. 2008. Altering the time of the second gonadotropin-releasing hormone injection and artificial insemination (AI) during Ovsynch affects pregnancies per AI in lactating dairy cows. J. Dairy Sci. 91:1044-1052.

Brusveen, D. J., A. H. Souza, and M. C. Wiltbank. 2009. Effects of additional prostaglandin $\mathrm{F}_{2 \alpha}$ and estradiol-17 $\beta$ during Ovsynch in lactating dairy cows. J. Dairy Sci. 92:1412-1422.

Buttrey, B. S., M. G. Burns, and J. S. Stevenson. 2010. Ovulation and pregnancy outcomes in response to human chorionic gonadotropin before resynchronized ovulation in dairy cattle. Theriogenology 73:449-459.

Caraviello, D. Z., K. A. Weigel, P. M. Fricke, M. C. Wiltbank, M. J. Florent, N. B. Cook, K. V. Nordlund, N. R. Zwald, and C. L. Rawson. 2006. Survey of management practices on reproductive performance of dairy cattle on large US commercial farms. J. Dairy Sci. 89:4723-4735.

Cerri, R. L., H. M. Rutigliano, R. C. Chebel, and J. E. Santos. 2009. Period of dominance of the ovulatory follicle influences embryo quality in lactating dairy cows. Reproduction 137:813-823.

Chebel, R. C., J. E. Santos, R. L. Cerri, H. M. Rutigliano, and R. G. Bruno. 2006. Reproduction in dairy cows following progester- one insert presynchronization and resynchronization protocols. J. Dairy Sci. 89:4205-4219.

Dewey, S. T., L. G. D. Mendonça, G. Lopes Jr., F. A. Rivera, F. Guagnini, R. C. Chebel, and T. R. Bilby. 2010. Resynchronization strategies to improve fertility in lactating dairy cows utilizing a presynchronization injection of $\mathrm{GnRH}$ or supplemental progesterone: I. Pregnancy rates and ovarian responses. J. Dairy Sci. 93:4086-4095.

Dias, F. C. F., M. G. Colazo, J. P. Kastelic, R. J. Mapletoft, G. P Adams, and J. Singh. 2010. Progesterone concentration, estradiol pretreatment, and dose of gonadotropin-releasing hormone affect gonadotropin-releasing hormone-mediated luteinizing hormone release in beef heifers. Domest. Anim. Endocrinol. 39:155-162.

Folman, Y., M. Kaim, Z. Herz, and M. Rosenberg. 1990. Comparison of methods for the synchronization of estrous cycles in dairy cows. 2. Effects of progesterone and parity on conception. J. Dairy Sci. 73:2817-2825.

Fricke, P. M., D. Z. Caraviello, K. A. Weigel, and M. L. Welle. 2003. Fertility of dairy cows after resynchronization of ovulation at three intervals following first timed insemination. J. Dairy Sci. 86:3941-3950.

Galvão, K. N., J. E. Santos, R. L. Cerri, R. C. Chebel, H. M. Rutigliano, R. G. Bruno, and R. C. Bicalho. 2007. Evaluation of methods of resynchronization for insemination in cows of unknown pregnancy status. J. Dairy Sci. 90:4240-4252.

Giordano, J. O., P. M. Fricke, J. N. Guenther, M. S. Ares, G. Lopes Jr., M. M. Herlihy, and P. M. Fricke. 2012a. Effect of presynchronization with human chorionic gonadotropin or gonadotropinreleasing hormone 7 days before resynchronization of ovulation on fertility in lactating dairy cows. J. Dairy Sci. 95:5612-5625.

Giordano, J. O., P. M. Fricke, J. N. Guenther, G. Lopes Jr., M. M. Herlihy, A. B. Nascimento, and M. C. Wiltbank. 2012b. Effect of progesterone on magnitude of the luteinizing hormone surge induced by two different doses of gonadotropin-releasing hormone in lactating dairy cows. J. Dairy Sci. 95:3781-3793.

Giordano, J. O., M. C. Wiltbank, J. N. Guenther, R. Pawlisch, S. Bas, A. P. Cunha, and P. M. Fricke. 2012c. Increased fertility in lactating dairy cows resynchronized with Double-Ovsynch compared with Ovsynch initiated $32 \mathrm{~d}$ after timed artificial insemination. J. Dairy Sci. 95:639-653.

Navanukraw, C., D. A. Redmer, L. P. Reynolds, J. D. Kirsch, A. T. Grazul-Bilska, and P. M. Fricke. 2004. A modified presynchronization protocol improves fertility to timed artificial insemination in lactating dairy cows. J. Dairy Sci. 87:1551-1557.

NRC. 2001. Nutrient Requirements of Dairy Cattle. 7th ed. Natl. Acad. Sci., Washington, DC.

Pursley, J. R., M. R. Kosorok, and M. C. Wiltbank. 1997. Reproductive management of lactating dairy cows using synchronization of ovulation. J. Dairy Sci. 80:301-306.

Rivera, F. A., L. G. D. Mendonça, G. Lopes Jr., J. E. P. Santos, R. V. Perez, M. Amstalden, A. Correa-Calderón, and R. C. Chebel. 2011. Reduced progesterone concentration during growth of the first follicular wave affects embryo quality but has no effect on embryo survival post-transfer in lactating dairy cows. Reproduction 141:333-342.

Sartori, R., J. M. Haughian, R. D. Shaver, G. J. Rosa, and M. C Wiltbank. 2004. Comparison of ovarian function and circulating steroids in estrous cycles of Holstein heifers and lactating cows. J. Dairy Sci. 87:905-920.

Silva, E., R. A. Sterry, D. Kolb, N. Mathialagan, M. F. McGrath, J. M. Ballam, and P. M. Fricke. 2009. Effect of interval to resynchronization of ovulation on fertility of lactating Holstein cows when using transrectal ultrasonography or a pregnancy-associated glycoprotein enzyme-linked immunosorbent assay to diagnose pregnancy status. J. Dairy Sci. 92:3643-3650.

Silva, E., R. A. Sterry, D. Kolb, M. C. Wiltbank, and P. M. Fricke. 2007. Effect of pretreatment with prostaglandin $\mathrm{F}_{2 \alpha}$ before resynchronization of ovulation on fertility of lactating dairy cows. J. Dairy Sci. 90:5509-5517.

Sterry, R. A., M. L. Welle, and P. M. Fricke. 2006a. Effect of interval from timed artificial insemination to initiation of resynchroniza- 
tion of ovulation on fertility of lactating dairy cows. J. Dairy Sci. 89:2099-2109.

Sterry, R. A., M. L. Welle, and P. M. Fricke. 2006b. Treatment with gonadotropin-releasing hormone after first timed AI improves fertility in noncycling lactating dairy cows. J. Dairy Sci. 89:42374245.

Stevenson, J. S., J. A. Cartmill, B. A. Hensley, and S. Z. El-Zarkouny. 2003. Conception rates of dairy cows following early not-pregnant diagnosis by ultrasonography and subsequent treatments with shortened Ovsynch protocol. Theriogenology 60:475-483.

Stevenson, J. S., M. A. Portaluppi, and D. E. Tenhouse. 2007. Factors influencing upfront single- and multiple-ovulation incidence, progesterone, and luteolysis before a timed insemination resynchronization protocol. J. Dairy Sci. 90:5542-5551.

Thompson, I. M., R. L. Cerri, I. H. Kim, J. A. Green, J. E. Santos, and W. W. Thatcher. 2010. Effects of resynchronization programs on pregnancy per artificial insemination, progesterone, and pregnancy-associated glycoproteins in plasma of lactating dairy cows. J. Dairy Sci. 93:4006-4018.

Vasconcelos, J. L., R. W. Silcox, G. J. Rosa, J. R. Pursley, and M. C. Wiltbank. 1999. Synchronization rate, size of the ovulatory follicle, and pregnancy rate after synchronization of ovulation beginning on different days of the estrous cycle in lactating dairy cows. Theriogenology 52:1067-1078.

Wiltbank, M. C., A. H. Souza, J. O. Giordano, A. B. Nascimento, J. M. Vasconcelos, M. H. C. Pereira, P. M. Fricke, R. S. Surjus, F. C. S. Zinsly, P. D. Carvalho, R. W. Bender, and R. Sartori. 2012. Positive and negative effects of progesterone during timed AI protocols in lactating dairy cattle. Anim. Reprod. 9:231-241. 